\title{
CHANGES IN THE ENGINEERING STUDENTS' PROCRASTINATION SELF- EVALUATION WITHIN THE EXPERIMENTAL APPROBATION OF CAREER EDUCATION PROGRAM
}

\author{
*Aleksandra Jerkunkova, Irena Katane, Regina Baltusite \\ Latvia University of Life Sciences and Technologies, Latvia \\ *Corresponding author's email: aleksandra.jerkunkova@1lu.lv
}

\begin{abstract}
One of the modern education problems being investigated is a phenomenon of student procrastination and minimisation of its influence on achievement of career goals. A transformative pedagogical experiment was carried out involving $1^{\text {st }}$ year engineering students of Latvia University of Life Sciences and Technologies during the 2018/2019 academic year. The aim of the transformative pedagogical experiment was to promote the reduction of student procrastination levels and achievement of their goals by practical experimental approbation of a career education program. During the experiment, self-evaluation of student procrastination was performed before and after the implementation of the career education program. The methodology included 20 indicators of procrastination self-evaluation. The program included three topic-based parts: 1) understanding and setting student career goals; 2) defining procrastination levels and factors; 3 ) the influence of procrastination minimisation on career goals' achievement. The study results allowed to conclude that due to the career education program elaborated and implemented in practice, substantial changes in student procrastination self-evaluation took place during the transformative pedagogical experiment. There was a significant difference in student procrastination levels before and after the transformative pedagogical experiment. The study results demonstrated that the elaborated and experimentally implemented career education program is valid and can be further used for minimisation of student procrastination, it can contribute to career goals' achievement and for the reduction of early discontinuation of studies and dropping out of university as there is a correlation between procrastination and dropout phenomena.
\end{abstract}

Key words: career development guidance; career education program; higher education; procrastination; students' self-evaluation.

\section{Introduction}

One of the modern education problems being investigated is a phenomenon of student procrastination and reduction of impact on career goals' achievement.

According to scientific publications (Klingsieck, 2013; Silkāne \& Austers, 2017; Steel, 2007), procrastination is characterised as a conscious delay of planned, essential and personally important activities regardless of the fact that negative consequences of such delay will prevail over the positive ones.

Unfortunately, a procrastinator in the result of procrastination is not able to plan time and perform self-management of tasks. The authors' experience shows that undesirable consequences of student procrastination include failure to complete independent study assignments and submit the assignments in a timely manner, non-attendance of lectures, worsening of mutual relations among students and teaching staff, deterioration in student attitude towards studies and change of their future careers, inability to adapt to university study environment. As a result of procrastination, students accumulate both academic and financial debts. All this can become a reason of early discontinuation of studies and dropping out of university.

Therefore, nowadays the research about procrastination including procrastination among university students remains a topical issue (Cheung \& Ng, 2019; Eisenbeck, Carreno, \& Ucles-Juarez,
2019; Fernie et al., 2019; Kljajic \& Gaudreau, 2018; Silkāne, 2018; Wessel, Bradley, \& Hood, 2019).

The phenomenon of procrastination occurs rather frequently and is not considered as a new, recently discovered phenomenon (Ellis \& Knaus, 1977; Wistrich, 2008), as it has been recorded that $90-95 \%$ of population have experienced procrastination at least once, which means that almost every individual has delayed or postponed a task. For chronic procrastinators, procrastination is some kind of selfdefence mechanism for avoiding difficulties, failures, stress in relation to deadlines of work submission, a negative emotional experience, etc. (Ferrari, Barnes, \& Steel, 2009; Ferrari et al., 2007), as they are accustomed to postpone important tasks without any real need and reason in various life situations and spheres.

Scientists T.P. Tibbett and J.R. Ferrari (Tibbett \& Ferrari, 2015) believe that a delay in task performance and decision making can be determined by various reasons and procrastination is some kind of a final result that is more based on a coincidence of various factors rather than on definite character traits of a certain person, yet they also matter. Scientists emphasise that typical procrastinators usually delay completion of tasks purposefully due to their own irrational reasons, at the same time being concerned about the delay.

However, the results of researches on procrastination carried out by scientists P. Steel and 
K.B. Klingsieck, (Steel, 2007, 2010; Klingsieck, 2016) show that: 1) if the level of procrastination is permanent in terms of time and different situations, there is a reason to consider that procrastination is a personal trait; 2) there is a close correlation between procrastination and dysfunctional impulsivity, poor self-direction and self-control.

Several researches have been carried out in recent years by the scientists D.E. Gustavson, et al., (2014) who carried out an in-depth study of possible relation between procrastination and impulsivity. Previous studies discovered moderate and positive correlation between procrastination and impulsivity. However, little was known about the reasons why these two constructs are connected. In the research done in 2014, the above mentioned scientists used a behaviourgenetics methodology to verify three forecasts based on a hypothesis that procrastination arises as a byproduct of impulsivity: 1) procrastination is heritable; 2) both traits have substantial genetic variations; 3 ) the ability of goal management is an important part of this common variation.

V. Silkane (Silkāne, 2018) points out that there are various types of procrastination: 1) active and passive procrastination; 2) procrastination of urge and avoidance; 3) procrastination of decision making.

The phenomenon of procrastination affects many areas of people's life including setting and achieving their career goals. The problem of procrastination that may cause a dropout is especially topical for the $1^{\text {st } y e a r ~ u n i v e r s i t y ~ s t u d e n t s, ~ a n d ~ i t ~ i s ~ d i r e c t l y ~}$ related to the process of adaptation to a new study environment. Higher education environment is distinctly different from educational environment at schools. The proportion of independent studies is bigger in the higher education environment, the role of self-management competence becomes more significant, including the aspect of time management. Since procrastination is closely related to selfmanagement (including self-regulation and selfcontrol), the following inference can be drawn: if the level of student self-management in terms of studies and career increases, the level of procrastination will decrease. To a great extent, it will allow students to avoid impulsive, sometimes ill-considered decisions in relation to early discontinuation of studies and dropping out of university.

To solve the problem of student procrastination in higher educational institutions by contributing to the reduction of their procrastination level, it is important to provide career development guidance by informing, educating and consulting students on the problem of procrastination, its consequences, examples, dropout risk.

The students' career development guidance (including career education and counselling) in university is one of higher education sustainable development priorities. This research problem is currently being investigated by a number of scientists (Carliner et al., 2015; Ford, 2015; Helyer \& Lee, 2014). The results of these researches, along with various career theories e.g., Gottfredson's Theory of Circumscription and Compromise; Holland's Theory of Vocational Personalities in Work Environment; Theory of Work-Adjustment, Self-concept; Theory of Career Development etc. (Brown \& Lent, 2017; Dahling \& Librizzi, 2015; Luke \& Redekop, 2019; Neff, 2017; Taber \& Blankemeyer, 2015) have become a methodological basis of an elaborated and experimentally approved career education program whose aim was to reduce student procrastination level and contribute to the achievement of career goals.

Within the framework of career development guidance, the essence of procrastination was explained to the students; they found out about themselves by analysing individual strengths and weaknesses, learned to manage personal life including their studies within higher education environment.

The aim of the research: to promote the reduction of student procrastination levels and achievement of their goals by practical experimental approbation of the career education program.

\section{Materials and Methods}

The research was carried out during the 2018/2019 academic year at Latvia University of Life Sciences and Technologies. It was a transformative experiment (a specific case study). Within the framework of the students' career development guidance the developed career education program for engineering students 'Reducing the Impact of Procrastination and Career Goals' Achievement' (10 academic hours) was experimentally approbated. The experimental group consisted of ten 1st year students of engineering.

The aim of the program was to reduce the level of student procrastination and to promote their career goals' achievement.

The program included three topic-based parts.

- Understanding and setting student career goals (3h).

- Defining procrastination levels and factors (2h).

- The influence of procrastination minimisation on career goals' achievement $(5 \mathrm{~h})$.

The elaborated program had a number of functions: informing, educating, promoting self-understanding, counselling.

Various methods of study have been used during the experiment: lectures, discussions, problem-based studies (independent group work) and individual work during workshops and practical training. 
The Table of Procrastination Results Calculation (Bulina, 2011)

Table 1

\begin{tabular}{|l|c|}
\hline \multicolumn{1}{|c|}{ Procrastination level } & The amount of points acquired \\
\hline Level 1. Low & $\ldots \leq 51$ \\
\hline Level 2. Average & $52 \leq 63$ \\
\hline Level 3. High & $64 \leq \ldots$ \\
\hline
\end{tabular}

Various methodologies are used by scientists in their researches for defining procrastination levels, for example:

- General Procrastination Scale (Lay, 1986);

- Adult Inventory of Procrastination (McCown, Johnson, \& Petzel, 1989).

- Decisional Procrastination Scale (Wieland et al., 2018);

- The Active Procrastination Scale (APS) (Choi \& Moran, 2019).

During the experiment, self-evaluation of student procrastination was performed before and after the implementation of the career education program by using a 'General Procrastination Scale' methodology (Lay, 1986), which is adapted and experimentally approved in Latvia by R. Buliņa (Buliņa, 2011). The methodology includes 20 indicators of procrastination self-evaluation. In accordance with each of these 20 indicators, the signs of procrastination were selfassessed based on a 5-point scale; the scores were as follows: very relevant ( 5 points); rather relevant (4 points); neither relevant nor irrelevant: neutral (3 points); rather irrelevant (2 points), not relevant at all (1 point). The procrastination level for each participant has been defined individually in accordance with the amount of points acquired. By using this methodology, three procrastination levels can be distinguished: low, average, high (Table 1).

The following research methods were used during the transformative experiment: 1) data obtaining: survey (questionnaires); 2) data processing: descriptive statistics ( $\sum$ of assessment points; mathematical values of procrastination level, differences between self-evaluation of procrastination, differences between procrastination levels); conclusive statistics, by using Wilcoxon Test (SPSS 21.0).

\section{Results and Discussion}

After the pedagogical experiment, the student procrastination self-assessments acquired before and after the elaborated career education program approbation were summarized.

The assessment amounts were defined by calculating them for each student individually in

Table 2

The Results of the Student Procrastination Level Self-Evaluation Before and After the Career Education Program Approbation: Descriptive Statistics

\begin{tabular}{|c|c|c|c|c|c|c|}
\hline \multirow{2}{*}{ Students } & \multicolumn{2}{|c|}{$\begin{array}{l}\text { Self-evaluation of } \\
\text { procrastination } \\
\left(\sum\right)\end{array}$} & \multirow[t]{2}{*}{ Differences } & \multicolumn{2}{|c|}{ Procrastination level } & \multirow{2}{*}{ Differences } \\
\hline & Before & After & & Before & After & \\
\hline & 58 & 59 & +1 & 2 & 2 & 0 \\
\hline & 56 & 51 & -5 & 2 & 1 & -1 \\
\hline & 53 & 46 & -7 & 2 & 1 & -1 \\
\hline & 45 & 39 & -6 & 1 & 1 & 0 \\
\hline & 54 & 55 & +1 & 2 & 2 & 0 \\
\hline & 57 & 56 & -1 & 2 & 2 & 0 \\
\hline & 52 & 45 & -7 & 2 & 1 & -1 \\
\hline & 51 & 44 & -7 & 1 & 1 & 0 \\
\hline & 56 & 48 & -8 & 2 & 1 & -1 \\
\hline & 53 & 52 & -1 & 2 & 2 & 0 \\
\hline & \multicolumn{2}{|c|}{ Positive differences: } & 2 & \multicolumn{2}{|c|}{ Positive differences: } & 0 \\
\hline & \multicolumn{2}{|c|}{ Negative differences: } & 8 & \multicolumn{2}{|c|}{ Negative differences: } & 4 \\
\hline & \multicolumn{2}{|r|}{ Ties: } & 0 & \multicolumn{2}{|r|}{ Ties: } & 4 \\
\hline
\end{tabular}


The Results of the Wilcoxon Test: Conclusive Statistics

\begin{tabular}{|c|l|c|l|}
\hline $\mathrm{N}$ & \multicolumn{1}{|c|}{ Data processing hypotheses } & The obtained results & \multicolumn{1}{c|}{ Conclusions } \\
\hline 1. & $\begin{array}{l}\mathrm{H}_{0}: \mathrm{SPPNS}_{1} *=\mathrm{SPPNS}_{2} * \\
\mathrm{H}_{1}: \mathrm{SPNS}_{1} \neq \mathrm{SPNS}_{2}\end{array}$ & $\mathrm{p}=0.021<\alpha=0.05$ & $\begin{array}{l}\text { There is a significant difference among the } \\
\text { student procrastination self-assessments sums } \\
\text { before and after the experiment. }\end{array}$ \\
\hline 2. & $\begin{array}{l}\mathrm{H}_{0}: \mathrm{SPL}_{1}^{*}=\mathrm{SPL}_{2}^{*} \\
\mathrm{H}_{1}: \mathrm{SPL}_{1} \neq \mathrm{SPL}_{2}\end{array}$ & $\mathrm{p}=0.046<\alpha=0.05$ & $\begin{array}{l}\text { There is a significant difference among the } \\
\text { student procrastination self-assessments levels } \\
\text { before and after the experiment. }\end{array}$ \\
\hline
\end{tabular}

*Abbreviation key

SPPNS $S_{1}$ : The sum of students' procrastination self-assessments before the experiment.

$\mathrm{SPPNS}_{2}$ : The sum of students' procrastination self-assessments after the experiment.

$\mathrm{SPL}_{1}$ : The level of students' procrastination self-assessments before the experiment.

$\mathrm{SPL}_{2}$ : The level of students' procrastination self-assessments after the experiment.

accordance with 20 procrastination indicators (in 5 points scale), summarizing all the obtained points. Therefore, the maximum possible score in the survey for each student was 100 points.

The level of procrastination was defined based on the table for procrastination results calculation (Table 1). The results of procrastination levels calculated in the table are placed on the nominal scale in accordance with the following alignment: High (Level 3) = 3; Average $($ Level 2$)=2$; Low $($ Level 1$)=1$ (Table 1 ; Table 2).

During the initial mathematical processing of the data obtained, descriptive statistical data were acquired (Table 2).

In accordance with the methodology for defining the procrastination level, the lower the self-assessment obtained, the better.

The values of the obtained self-assessment sums (Table 2) demonstrate that the self-assessments of all 10 students changed: the self-assessment of procrastination of 8 students reduced, while the selfassessment of 2 students increased.

Before the approbation of the elaborated career education program, the level of procrastination was defined as average for 8 of 10 students, and 2 students had a low procrastination level. In its turn, after the experiment, the obtained results of the research demonstrated that 4 students only retained the average procrastination level, while 8 students had a low procrastination level. The results allowed to conclude that the self-assessments made by 4 of 10 students experienced outstanding changes, as their self-assessments reduced from the average to low procrastination level (Table 2).

In order to define whether any statistically significant changes in self-evaluation of procrastination took place during the pedagogical experiment, the amounts of self-evaluation obtained before and after the approbation of the career education programme called 'Reducing the Impact of Procrastination and
Career Goals' Achievement' and the procrastination levels were compared.

The data were processed by using the Wilcoxon Test in the SPSS 21.0 software application, obtaining the results of conclusive statistics (Table 3 ).

The conclusive statistic results show that due to the career education program elaborated and implemented in practice, significant changes in the self-evaluation of student procrastination took place during the transformative pedagogical experiment. There are significant differences between the students' procrastination levels before and after the experiment as well (Table 3).

Discussion. Theoretical studies results show that procrastination is one of the reasons of the students' dropout. The correlation between procrastination and dropout phenomena is confirmed by the results of studies that can be found in various scientific publications (Bardach et al., 2019; Bäulke, Eckerlein, \& Dresel, 2018; Grau \& Minguillon, 2013; Gubbels, Put, \& Assink, 2019). This means that during the transformative experiment, along with the minimisation of the influence of procrastination phenomenon on the participants of the experiment ( $1^{\text {st }}$ year engineering students), the dropout risk was minimised as well.

\section{Conclusions}

1. There are significant differences in self-evaluation of student procrastination before and after the transformative pedagogical experiment. There are significant differences between the students' procrastination levels before and after the experiment as well.

2. During the transformative pedagogical experiment (due to the career education program elaborated and implemented in practice), students gained experience of self-management, including selfevaluation, in relation to procrastination and achievement of their career goals. 
3. Based on results of theoretical research, it can be said that the dropout risk in the experimental group of $1^{\text {st }}$ year students was reduced along with the minimisation of their procrastination level.

4. The aim of the elaborated and experimentally approved career education programme has been achieved and the tasks have been accomplished.
5. The elaborated and experimentally approbated career education program is valid and can be further implemented for minimisation of student procrastination, it can contribute to career goals' achievement, and it can be used for the reduction of a dropout risk as there is a correlation between procrastination and dropout phenomena.

\section{References}

Bardach, L., Lftenegger, M., Oczlon, S., Spiel, Ch., \& Schober, B. (2019). Context-related problems and university students' dropout intentions-the bufferins effect of personal best goals. European Journal of Psyhology of Education, 35, 477-493.DOI:10.1007/s10212-019-00433-9.

Bäulke, L., Eckerlein, N., \& Dresel, M. (2018). Interrelations between motivational regulation, procrastination and college dropout intentions. Unterrichtswissenschaft, 46(4), 461-479. DOI: 10.1007/s42010-0180029-5.

Brown, S.D., \& Lent, R.W. (2017). Social cognitive career theory in a diverse world: Closing thoughts. Journal of Career Assessment, 25(1), 173-180. DOI: 10.1177/1069072716660061.

Bulina, R. (2011). Relations Between Adaptive and Maladaptive Perfectionism, Self-Efficacy, and Subjective Well-Being. Psychology Research, 4(10), 835-842.

Carliner, S., Castonguay, C., Sheepy, E., Ribeiro, O., Sabri, H., Saylor, C., \& Valle, A. (2015). The job of a performance consultant: a qualitative content analysis of job descriptions. European Journal of Training and Development, 39(6), 458-483. DOI: 10.1108/EJTD-01-2015-0006.

Cheung, R.Y.M., \& Ng, M.C.Y. (2019). Being in the moment later? Testing the inverse relation between mindfulness and procrastination. Personality and Individual Differences, 141, 123-126. DOI: 10.1016/j. paid.2018.12.015.

Choi, J.N., \& Moran, S.V. (2009). Why not procrastinate? Development and validation of a new active procrastination scale. The Journal of Social Psychology, 149, 195-212. DOI: 10.3200/SOCP.149.2.195212.

Dahling, J.J., \& Librizzi, U.A. (2015). Integrating the theory of work adjustment and attachment theory to predict job turnover intentions. Journal of Career Development, 42(3), 215-228. DOI: 10.1177/0894845314545169.

Eisenbeck, N., Carreno, D.F., \& Ucles-Juarez, R. (2019). From psychological distress to academic procrastination: Exploring the role of psychological inflexibility. Journal of Contextual Behavioral Science, 19, $103-108$. DOI: $10.1016 /$ j.jcbs.2019.07.007.

Ellis, A., \& Knaus, W.J. (1977). Overcoming Procrastination. New York: Institute for Rational Living.

Ferrari, J.R., Barnes, K.L., \& Steel, P. (2009). Life regrets by avoidant and arousal procrastinators. Journal of Individual Differences, 30(3), 163-168. DOI: 10.1027/1614-0001.30.3.163.

Ferrari, J.R., Diaz-Morales, J.F., O’Callaghan, J., Diaz, K., \& Argumedo, D. (2007). Frequent behavioral delay tendencies by adults: International prevalence rates of chronic procrastination. Journal of Cross-Cultural Psychology, 38(4), 458-464. DOI: 10.1177/0022022107302314.

Fernie, B.A., Kopar, U.Y., Fisher, P.L., \& Spada, M.M. (2019). Further development and testing of the metacognitive model of procrastination: Self-reported academic performance. Journal of Affective Disorders, 240, 1-5. DOI: 10.1016/j.jad.2018.07.018.

Ford, M. (2015). Rise of the Robots: Technology and the Threat of a Jobless Future. New York: Basic Books.

Grau, J., \& Minguillon, J. (2013). When procrastination leads to dropping out: analysing students at risk. $e L C$ Research Paper Series, 6, 63-74. Retrieved November 13, 2019, from https:/www.raco.cat/index.php/ eLearn/article/view/272013/359965.

Gubbels, J., van der Put, C.E., \& Assink, M. (2019). Risk Factors for School Absenteeism and Dropout: A MetaAnalytic Review. Journal of Youth and Adolescence, 48, 1637-1667. DOI: 10.1007/s10964-019-01072-5.

Gustavson, D.E., Miyake, A., Hewitt, J.K., \& Friedman, N.P. (2014). Genetic relations among procrastination, impulsivity, and goal-management ability: Implications for the evolutionary origin of procrastination. Psychological Science, 25(6), 1178-1188. DOI: 10.1177/0956797614526260.

Helyer, R., \& Lee, D. (2014). The Role of Work Experience in the Future Employability of Higher Education Graduates. Higher Education Quarterly, 68(3), 348-372. DOI: 10.1111/hequ.12055.

Klingsieck, K.B. (2013). Procrastination: When Good Things Don't Come to Those Who Wait. European Psychologist, 18(1), 24-34. DOI: 10.1027/1016-9040/a000138. 
Kljajic, K., \& Gaudreau, P. (2018). Does it matter if students procrastinate more in some courses than in others? A multilevel perspective on procrastination and academic achievement. Learning and Instruction, 58, 193-200. DOI: 10.1016/j.learninstruc.2018.06.005.

Lay, C. (1986). At last, my research article on procrastination. Journal of Research in Personality, 20, 474-495. DOI: 10.1016/0092-6566(86)90127-3.

Luke, C., \& Redekop, F. (2019). Gottfredson's Theory: Application of Circumscription and Compromise to Career Counseling. In G. Eliason, J. Patrick, J. Samide, \& L. Lepore (Eds.), Career development across the lifespan: Counseling for Community, Schools, Higher Education, and Beyond ( ${ }^{\text {nd }}$ Edition), A Volume in: Issues in Career Development (pp. 61-79). Harlotte, NC: Information Age Publishing, Inc.

McCown, W.G., Johnson, J.L., \& Petzel, T. (1989). Procrastination, a principal components analysis. Personality and Individual Differences, 10(2), 197-202.

Neff, W. (2017). Work and human behavior. London: Routledge.

Silkāne, V. (2018). Prokrastinācijas, diskontēšanas un personības iezīmju saistība ar veselības uzvedību (Relationship of procrastination, discounting, and personality traits to health behaviors). Doctoral Thesis. Riga: University of Latvia. (in Latvian).

Silkāne, V., \& Austers, I. (2017). Personības, diskontēšanas un uzdevuma raksturojuma loma prokrastinācijas un veselības prokrastinācijas skaidrošanā (Personality Traits, Time Discounting, and Task Characteristics in Explaining Procrastination and Health Procrastination). Baltic Journal of Psychology, 18 (1,2), 40-58. (in Latvian).

Steel, P. (2007). The nature of procrastination: A meta-analytic and theoretical review of quintessential selfregulatory failure. Psychological bulletin, 133(1), 65-94. DOI: 10.1037/0033-2909.133.1.65.

Steel, P. (2010). The procrastination equation: How to stop putting things off and start getting stuff done. Random House Canada. New York: Harper, c2011.

Steel, P., \& Klingsieck, K.B. (2016). Academic procrastination: Psychological antecedents revisited. Australian Psychologist, 51(1), 36-46. DOI: 10.1111/ap.12173.

Taber, B.J., \& Blankemeyer, M. (2015). Future work self and career adaptability in the prediction of proactive career behaviors. Journal of Vocational Behavior, 86, 20-27. DOI: 10.1016/j.jvb.2014.10.005.

Tibbett, T.P., \& Ferrari, J.R. (2015). The portrait of the procrastinator: Risk factors and results of an indecisive personality. Personality and individual differences, 82, 175-184.

Wieland, L.M., Grunschel, C., Limberger, M.F., Schlotz, W., Ferrari, J.R., \& Ebner-Priemer, U.W. (2018). The ecological momentary assessment of procrastination in daily life: Psychometric properties of a five-item short scale. North American Journal of Psychology, 20(2), 315-339.

Wessel, J., Bradley, G., \& Hood, M. (2019). Comparing effects of active and passive procrastination: A field study of behavioral delay. Personality and Individual Differences, 139, 152-157. DOI: 10.1016/j. paid.2018.11.020.

Wistrich, A.J. (2008). Procrastination, deadlines, and statutes of limitation. William \& Mary Law Review, 50(2), $607-667$. 